\title{
DISPAREUNIA, VAGINISMO E INIBIÇÃO DE DESEJO SEXUAL
}

\author{
Carla Zeglio ${ }^{\prime}$
}

Embora a dor seja o sintoma que caracteriza tanto o vaginismo quanto a dispareunia, seja a dor uma real sensação, ou o motivo do medo que impede a relação sexual de ser prazerosa... afirmo que o real problema pode ser a IDS - Inibição do Desejo Sexual - que leva à vivência do vaginismo e da dor coital.

Um exemplo pode conduzir a esta compreensão.

Andréa, 36 anos, solteira, heterossexual, primeira filha de imigrantes portugueses, fisioterapeuta, com queixa inicial de vaginismo e dispareunia, concomitantemente aperentava apnéia, em situações sexuais. Eram características presentes: educação sexual repressiva; manutenção de crenças e preconceitos que só levam a frustrações, desprazer e sofrimento pessoal; desconhecimento e falta de informação sexual; falta de experiência sexual; estresse, esgotamento e excesso de trabalho; intensa ansiedade; medos irracionais diante de situações sexuais; recuperação de enfermidades recentes; medo da gravidez; culpa diante da expressão da sexualidade; dificuldade de dizer ao parceiro do que gosta; insatisfação com a parceria; maus tratos pela parceria; falta de amor pelo parceiro; relacionamento de conveniência; falta de confiança no parceiro; fantasias sexuais com culpa; não conhecimento 
das próprias necessidades. E, finalmente, falta do desejo sexual, em função dos itens anteriores.

0 vaginismo e a dispareunia diagnosticados como psicogênicos, talvez sejam apenas os sintomas de um mundo feminino inexplorado e, muitas vezes, tido como pecado. 0 mais importante não é buscar uma causa, mas sim compreender como a mulher se situa subjetivamente, diante do mundo e das vivências de sua sexualidade. A partir dai, iniciarmos o processo de reescrever a história, com possibilidade de saúde mental e qualidade de vida sexual. 